\title{
INFORMATION AND COMMUNICATION TECHNOLOGY WITHIN ENGLISH FOR ACADEMIC PURPOSES STUDIES
}

\author{
SUMMARY \\ Introduction. The use of Information and Communication Technology and of 3-5 languages is of \\ the greatest importance today in order to form varied cooperative networks for the creation of new \\ knowledge.
}

Aim of the Study. To offer activities with the use of ICT within the English for Academic Purposes studies.

Materials and Methods. The search for activities within English for Academic Purposes studies involves a process of analyzing the meaning of key concepts and demonstrates how the key concepts are related to the term of ICT.

Results. The study presents a potential model for development indicating how the steps of the process are related.

Conclusion. Activities with the use of Information and Communication Technology offer many interesting opportunities for studying English for Academic Purposes.

Key words: information and communication technology, english for academic purposes studies

\section{INTRODUCTION}

The concern of the European Union is to become "the most competitive and dynamic knowledge-based economy in the world capable of sustainable economic growth with more and better jobs and greater social cohesion" (European Commission, 2004).

In order to achieve this ambitious aim Europe's people are realized as its most important asset (Commission Memorandum, 2000). Moreover, every human becomes a value for the whole society (Maslo I., 2006).

For the development of humans, institutions, society and mankind, of the greatest importance are:

- independent and responsible, original in terms of viewpoints and opinions, general view of life and action;

- the use of Information and Communication Technology and

- the use of 3-5 languages, with at least 2-3 on the level of native/first language in order to form varied cooperative networks for the creation of new knowledge (Maslo E., 2006),

The tertiary level of education that is a key sector of the knowledge-based economy and society and is at the heart of the "knowledge triangle" of education, innovation and research (European Commission, 2006) is important for enabling new specialists to use Information and Communication Technology in a multilingual environment.

\section{AIM OF THE STUDY}

To offer activities with the use of Information and Communication Technologies within English for Academic Purposes studies. 


\section{MATERIALS AND METHODS}

The search for activities within English for Academic Purposes studies involves a process of analysing the meaning of key concepts English for Academic Purposes in English Language Teaching/Learning, English for Academic Purposes studies. Moreover, the study demonstrates how the key concepts are related to the term of Information and Communication Technology. The study presents a potential model for development indicating how the steps of the process are related following a logical chain: English language learning $\rightarrow$ English for Academic Purposes studies $\rightarrow$ content and research integrated studying $\rightarrow$ activities with the use of Information and Communication Technology within English for Academic Purposes studies.

\section{Information and Communication Technology within Foreign Language Learning}

Today the provisions for a European Qualifications Framework, European Research Council, programmes such as Comenius and Erasmus contribute to use Information and Communication Technology as a learning/teaching tool and English as a learning/teaching language (Druviete, 2007) within the activities of professional learning where English is a foreign language.

According to E. Maslo (Maslo, 2007), all learning is part of a single process, an ongoing process. This finding suggests that professional learning and/or both Information and Communication Technology learning and foreign language learning are part of a single learning process in the professional development.

\section{Defining Foreign Language Learning}

Experience in the use of Information and Communication Technology and of 3-5 language and cooperative skills allows for everyone to become more mobile and to learn from the experience of others altogether with compensation of certain elements of experience which are not typical for his/her own country (Maslo I., 2006). It makes every job better and more understandable not only for one country but for the whole wider world.

Realizing the use of 3-5 languages Robbins (Robbins, 2007) points out that First Language, Second Language, Third Language, Fourth Language are linked, united in various ways, forming a whole.

The task of the European educational systems is to raise linguistic personalities being able to communicate in foreign languages. Communication in foreign languages also calls for skills such as mediation and intercultural understanding. An individual's level of proficiency will vary between the four dimensions (listening, reading, writing, speaking) and between the different languages, and according to that individual's social and cultural background environment, needs and/ot interests.

The area of the Foreign Language Pedagogy's interest as the process of foreign language learning determined by E. Maslo (Maslo, 2007) is focused on the pedagogical process that promotes any learning.

Moreover, E. Maslo determines that learning and studying are kinds of research process (Maslo, 2007) that is a systematic process of inquiry consisting of three elements: a question, problem, or hypothesis; data, and analysis; interpretation of data (Nunan, 1992).

It puts the emphasis on research within Information and Communication Technology learning and foreign language learning as potential for professional development.

\section{English for Academic Purposes in English Language Teaching/Learning}

First it is necessary to establish how English for Academic Purposes relates to English Language Teaching/Learning. T. Hutchinson and A. Waters (Hutchinson and Waters, 1994) 
represent it in the form of a tree: the tree of English Language Teaching/Learning is nourished by its roots which are learning and communication. There are three branches of English Language Teaching/Learning. One of them is called English as a Foreign Language (EFL) that is divided into two branches: General English (GE) and English for Specific Purposes (ESP).

The branch of English for Specific Purposes (ESP) has three branches, too. This division depends on the purpose of studying English: English for Science and Technology (EST); English for Business and Economics (EBE); English for Social Science (ESS).

Every of these branches is divided into two: for work and for academic study which have their own branches and show the level that is needed by learners. The field of our concern is English for Academic Purposes.

Thus, English for Academic Purposes is a brach of English for Specific Purposes in English language learning.

\section{Defining English for Academic Purposes}

Study skills were coming increasingly to the fore in the 1970s in practice material for students of English.

The first recorded use of the term "English for Academic Purposes" appears to be in 1974 in order to describe the need of English students in study skills; by 1975 it was in more general use.

A provisional, rather general, working definition of English for Academic Purposes is that "English for Academic Purposes is concerned with those communication skills in English which are required for study purposes in formal education systems" (ETIC 1975 by Jordan, 1997).

English for Academic Purposes in Latvia relates to Level 7 among 8 educational stages of the European Qualification Framework (Martyniuk, 2006). Level 7 is defined by a set of descriptors indicating the learning outcomes relevant to qualifications at that level in any system of qualification (European Qualification Framework, 2006):

- knowledge: highly specialized knowledge, some of which is at the forefront of knowledge in a field of work or study, as the basis for original thinking; critical awareness of knowledge issues in a field and at the interface between different fields;

- skills: specialized problem-solving skills required in research and/or innovation in order to develop new knowledge and procedures and to integrate knowledge from different fields;

- competence: manage and transform work or study contexts that are complex, unpredictable and require new strategic approaches; take responsibility for contributing to professional knowledge and practice and/or for reviewing the strategic performance of teams.

English for Academic Purposes has two divisions: common core or subject - specific (Jordan, 1997).

These two divisions have been described by Blue (quoted by Jordan, 1997) as English for General Academic Purposes (EGAP) and English for Specific Academic Purposes (ESAP).

A large proportion of the common core element is more usually known as "study skills", e. g. listening and note-taking (Jordan, 1997). When the development of student's study skills to an appropriate level for the subject(s) to be studied is achieved, he/she then has to "learn the academic code" that involves a number of elements, depending on the level of education being pursued, i. e. undergraduate, post-graduate, research (Jordan, 1997).

Also, the point is crucial that more than often academic activities bear a research character and thus the use of English for academic purposes cannot be strictly separated from the use of English for research purposes (Kramiņa, 2000). 
Subject-specific English is the language needed for a particular academic subject, e.g. economics, together with its disciplinary culture. It includes the language structure, vocabulary, the particular skills needed for the subject, and the appropriate academic conventions (Jordan, 1997).

R. Jordan (Jordan, 1997) tries to find out what distinguishes one discipline from another: the subject content; rhetorical organization; the underlying conceptual approach to the subject. This is part of the difference that is expressed through the disciplinary culture, of which specific expectations and conventions are an integral part.

Thus, it is possible to define English for Academic Purposes as the subject content and language research.

\section{Defining English for Academic Purposes Studies}

Researchers (Robbins, 2007; Maslo, 2007) in the field of language learning recognise that all language learning is placed within a single continuum, with varying capacities where foreign language learning and studying are kind of research process (Maslo E., 2006; 2007).

Thus, the definition of English for Academic Purposes such as the subject content and language research allows define English for Academic Purposes studies on prevailing pedagogical discourse as content and research integrated studying.

Activities with the Use of Information and Communication Technology within English for Academic Purposes Studies

A variety of activities with the use of Information and Communication Technology can be applied to promote the development of English for Academic Purposes Studies:

\section{Information-gap Activity:}

Games are designed to provoke communication between students frequently depend on an information gap, so that one student has to talk to a partner in order to solve a puzzle, draw a picture, put things in the right order, or find similarities and differences between pictures (Harmer, 2001).

To start a communication game in the class of English for Academic Purposes, C. Kennedy and R. Bolitho (Bolitho, 1984) suggest that the teacher first decides what language and skills he wants to be practised by the learners.

Communication games are to simulate professional teamwork that calls upon the expertise of different people to solve problems. As in a professional context, group members are encouraged to think creatively, to integrate information, and to come to a consensus on the alternatives they have generated (Gonzalez, Pratt, 1994).

The following activities with the Use of Information and Communication Technology are used to promote the development of English for Academic Purposes Studies at tertiary level:

- the Search of Professional Information on the Internet. The list of questions is as follows:

Dear student,

Please, work on the Internet in the computer classroom and find the following information:

1. search engines:

2. Internet dictionaries:

3. names and web-addresses of your professional associations in Latvia, in Europe, in the world:

4. web-addresses that contain information on your speciality's courses and seminars in Latvia, in Europe, in the world:

5. web-addresses of magazines useful for your speciality: 
6. web-addresses of newspapers useful for your speciality:

7. web-addresses of teaching methodology for educatuonal workers:

8. web-addresses of projects for your speciality:

9. web-addresses about the subject you are going to teach:

10. web-addresses of vacancies for your speciality in Latvia, in Europe, in the world:

11. any other useful web-sites for your speciality: chatting, blogs, Classroom management Systems:

Thank you for your co-operation!

- Preparing a Good Introduction to a Presentation. The task is formulated in the following way:

Dear student,

- Reorder these sentences so that they make a good introduction to a presentation. Put the number of the sentence into the correct column of the table;

- Fill in each gap $(7,8,9,10)$ in the sentences. You can use more than one word in each space. Follow the definitions in the text given in small letters.

1. I will be talking for about 30 minutes and there will be time for questions at the end of my presentation.

2. On behalf of the Senate of (7) the name of the academy _ may I welcome you to the General Annual Meeting.

3. I am responsible for co-ordinating all of the managing work (8) the name of your department

and co-ordinating our work with our partners in Europe.

4. My name is (9) your name and surname __ and I am (10) your position in the academy _.

5. This morning I would like to outline our strategy for getting more partners in the European Union.

6. Good morning, ladies and gentlemen.

- Completing the Europass Language Passport. The link is:

http://europass.cedefop.europa.eu/europass/home/hornav/Downloads/LangPassport/ ELPTemplate/navigate.action

- Completing the Europass $\boldsymbol{C V}$. The link is:

http:/europass.cedefop.europa.eu/europass/home/hornav/Downloads/EuropassCV/CVTemplate/ navigate.action.

Information-gap activities are usually structured in the following way:

Level Intermediate, upper-intermediate

Materials Each student will need to get a task connected with their job, profession, or company.

Time 130 minutes

Aim To focus on reading, writing, listening and speaking; asking and answering questions, searching for information on the Internet

Preparation To send the students an e-mail containing the task and/or the necessary link 
Procedure 1. In class ask the students to read out the task. Clarify it if necessary.

2. The students individually and/or in pairs search for the information on the Internet in order to answer the given questions.

3. The students share their experience and answers with the rest of the group.

4. The students compare their findings with the findings of the other students.

5. The students complete the question list with all of the possible answers mentioned in the classroom.

\section{Prepared Talk:}

Prepared talk is a popular kind of activity (Harmer, 2001). It is when a student (or students) makes a presentation on a topic of their own choice.

Research on the topics of the student's presentations reveals 3 of the greater importance:

- an article/book/conference materials/etc relevant to the students' professional interest;

- Successful Teacher/Educational Manager/Psychologist/Builder/Engineer/etc (relevant to the field of student's study);

- Student's Term/Course/Bachelor/Master Paper (relevant to the level of student's study);

Prepared talks if properly organised can be extremely interesting for both speaker and listeners (Harmer, 2001).

The organisation of the prepared talk activity is as follows:

\section{Level Intermediate, upper-intermediate}

Materials Articles on the Internet and/or in the library relevant to the interest and level of the group; the PowerPoint programme

Time $\quad 130$ minutes

Aim To focus on the development of formal spontaneous talk from notes with the use of the PowerPoint programme

Procedure 1. Everyone chooses an article to read. This is done at home. It is important that students read individually.

2. Tell everyone to prepare a presentation on the article with the use the PowerPoint programme at home.

3. A student tells his/her groupmates about his/her article with the use the PowerPoint programme.

4. The students switch the roles of speakers and listeners and repeat the activity.

5. The students then write a reflection on their presentations.

\section{Discussion:}

The most natural and effective way for learners to practise talking freely in English is by thinking out some problems or situation together through verbal interchange of ideas; or in simpler terms, to discuss (Ur, 1981).

A successful discussion is characterised by full participation and high motivation of the students where language is used in a variety of ways in terms of subject-matter and communication functions (Ur, 1981).

One of the ways of discussing with the use of Information and Communication Technology is possible to try Classroom Management System on www.nicenet.org: 
Level Intermediate, upper-intermediate

Materials Any topic within the English for Academic Purposes studies

Time

Aim 130 minutes

Preparation

To focus on reading, writing; making hypotheses, predicting

Procedure

To create a class on www.nicenet.org

1. Ask the students to enter the Classroom Management System and to do a task/to share their links connected with their professional field/to chat/etc.

2. Ask the students to discuss how they can apply this knowledge about the Classroom Management System when working on their own.

3. Ask the students to write down their own point of view on www.nicenet. org/conferencing

\section{RESULTS}

The study presents a potential model for development indicating how the steps of the process are related following a logical chain: English language learning $\rightarrow$ English for Academic Purposes studies $\rightarrow$ content and research integrated studying $\rightarrow$ activities with the use of Information and Communication Technology within the English for Academic Purposes studies.

\section{CONCLUSION}

Activities with the use of Information and Communication Technology offer many interesting opportunities for studying English for Academic Purposes as part of professional learning.

\section{REFERENCES}

1. Commission of the European Communities (2006) Communication from the Commission to the Council and to the European Parliament Efficiency and Equity in European Education and Training Systems. Brussels, 8.9.2006, 7 p.

2. Commission of the European Communities (2006) Implementing the Community Lisbon Programme. Proposal for a Recommendation of the European Parliament and of the Council on the Establishment of the European Qualification Framework for Lifelong Learning. Brussels, 5.9.2006, 19 p.

3. Druviete, I. (2007) Identity, Language Diversity. Multilingualism: Challenges for the $21^{\text {st }}$ Century Education Systems. International Nordic-Baltic Region Conference of FIPLV Innovations in Language Teaching and Learning in the Multicultural Context 15-16 $6^{\text {th }}$ June, 2007, Riga, p. 12., 13.

4. European Commission Directorate-General for Education and Culture (2004) Implementation of "Education and Training 2010" Work Programme. Working Group A "Improving the Education of Teachers and Trainers". Progress Report September 2004, 2 p.

5. European Commission Directorate-General for Education and Culture (2000) Commission Memorandum of 30 October 2000 on lifelong learning [SEC(2000) 1832 final. http://europa.eu/scadplus/leg/en/cha/ c11047.htm, 1 p.

6. Gonzalez, J., Pratt, E. (1994) One-Credit Professional Communications Courses for Development and Maintenance of Oral Skills. TESOL Journal Volume 3, Number 4, Summer 1994, 18 p.

7. Harmer, J. (2001) The Practice of English Language Teaching. London: Longman, p. 272, 274.

8. Hutchinson, T., Waters, A. (1986) English for Specific Purposes. Cambridge University Press, p. 1618. 
9. Jordan, R. R. (1997) English for Academic Purposes: A Guide and Resource Book for Teachers. London: Cambridge University Press, p. 1, 4, 6, 249, 250.

10. Kennedy, C., Bolitho, R. (1984) English for Specific Purposes. London: Macmillan Publishers Ltd, $128 \mathrm{p}$.

11. Kramiņa, I. (2000) Lingo - Didactic Theories Underlying Multi - Purpose Language Acquisition. Riga: University of Latvia, $40 \mathrm{p}$.

12. Martyniuk, W. (2006, October) European Frameworks of Reference for Language Competences. Language Policy Division, Strasbourg, Intergovernmental Conference Languages of Schooling: toward a Framework for Europe (p. 1-19) Strasbourg 16-18, October, 2006, 16 p.

13. Maslo, E. (2006) Skolēnu, skolotāju, studentu un docetāju spēju pilnveide savas mācīšanās izpētes procesā. In: I. Maslo (Eds.) No zināšanām uz kompetentu darbību [From Knowledge to Competent Activity]. Rīga: Latvijas Universitātes Akadēmiskais apgāds, 59. lpp.

14. Maslo, E. (2007) Transformative Learning Space for Life-Long Foreign Languages Learning. International Nordic-Baltic Region Conference of FIPLV Innovations in Language Teaching and Learning in the Multicultural Context 15-16 $6^{\text {th }}$ June, 2007, Riga, p. 38, 41.

15. Maslo, I. (2006) Introduction. In: I. Maslo (Eds.) No zināšanām uz kompetentu darbību [From Knowledge to Competent Activity]. Rīga: Latvijas Universitātes Akadēmiskais apgāds, 15., 16. lpp.

16. Nunan, D. (1992) Research Methods in Language Learning. Cambridge: Cambrigde University Press, $3 \mathrm{p}$.

17. Robbins, D. (2007) Vygotsky's and Leontiev's Non-classical Psychology Related to Second Language Acquisition. International Nordic-Baltic Region Conference of FIPLV "Innovations in Language Teaching and Learning in the Multicultural Context. 15-16, June, 2007, Riga, p. 52.

18. Ur, P. (1981) Discussions that Work. London: Cambridge University Press, p. 2-4.

Mg. paed. Jel̦ena Zaščerinska

Doctoral student of University of Latvia

Address: Kurzemes pr. 114-102, Rīga, LV-1069

Phone: +371 29435142

E-mail: jelena.zascerinska@rpiva.lv 